\title{
Lesion regeneration capacities in populations of the massive coral Porites lutea at Réunion Island: environmental correlates
}

\author{
V. Denis ${ }^{1, *}$, J. Debreuil ${ }^{1,3}$, S. De Palmas ${ }^{1}$, J. Richard $^{1,4}$, M. M. M. Guillaume ${ }^{1,2}$, \\ J. H. Bruggemann ${ }^{1}$ \\ ${ }^{1}$ Laboratoire d'Ecologie Marine, Université de la Réunion, BP 7151, 97715 Saint-Denis, La Réunion, France \\ ${ }^{2}$ Département Milieux et Peuplements Aquatiques, UMR CNRS-MNHN-UPMC-IRD BOrEA, Muséum National d'Histoire \\ Naturelle, 61 rue Buffon, 75005 Paris, France \\ ${ }^{3}$ Present address: Centre Scientifique de Monaco, Avenue Saint Martin, MC98000, Monaco \\ ${ }^{4}$ Present address: British Antarctic Survey, High Cross, Madingley Road, Cambridge CB30ET, UK
}

\begin{abstract}
The capacity of corals for repairing partial mortality is a fundamental determinant of reef resilience. This capacity was assessed in the major reef-building coral Porites lutea by monitoring the regeneration of artificially induced lesions of standard size (330 $\pm 50 \mathrm{~mm}^{2}, 3 \mathrm{~mm}$ deep) in 4 shallow reef flat populations at Réunion Island, under different environmental conditions related to sites and seasons, during a period without positive temperature anomalies. An exponential decay model with an asymptote described the lesion regeneration through 14 experiments. In spite of fast initial lesion regeneration, limited capacity for repair in this massive coral was indicated, as only $18 \%$ of the inflicted lesions healed completely within 6 to 9 mo. Lesion regeneration was fastest and most complete in the cooling and cool seasons, and may be impaired during the warming and hot seasons. Both solar radiation and seawater temperature contributed to seasonal changes in regeneration capacity, although they had opposite effects. While high radiation during the warming season decreased lesion regeneration rate, potentially through reduction of the photosynthetic efficiency of zooxanthellae, high temperature boosted it but also increased the amount of lesion area that could not be regenerated. Study sites were characterised by different temperature and radiation regimes, but these parameters alone could not explain all site effects on lesion regeneration capacity. Additional factors, most probably chronic stress caused by inputs of organic matter and run-off from land, may further compromise the regeneration capacity of corals and the resilience of coral populations.
\end{abstract}

KEY WORDS: Scleractinia $\cdot$ Partial mortality $\cdot$ Resilience $\cdot$ Reproduction $\cdot$ Sea surface temperature Solar radiation $\cdot$ Western Indian Ocean

\section{INTRODUCTION}

Scleractinian corals are damaged by a multitude of biotic and abiotic factors, resulting in chronic or acute tissue loss from colonies (Bythell et al. 1993, Connell 1997 ) to profound reductions of living coral cover on reefs (Goreau et al. 2000). Predation, diseases, competitive interactions, emersion, storms, sedimentation, temperature anomalies and human activities may all result in partial mortality of the coral colony (DeVantier \& Done 2007). Coral bleaching, the loss of symbiotic zooxanthellae following anomalous high temperatures in synergy with high light intensities, also often leads to partial mortality in affected parts of the colony, rather than the death of the entire colony (Jones 2008). Colony survival and community recovery 
will, in part, depend on the regenerative capacities of remnant coral colonies (Hughes \& Jackson 1985). DiazPulido et al. (2009) showed that rapid, large-scale recovery of coral communities after severe bleaching depended largely on the survival and re-growth of remnant coral tissue and identified regeneration capacity as a key determinant of coral reef resilience.

The clonal architecture of coral colonies facilitates the repair of partial mortality by the reallocation of resources among units (Oren et al. 1997a), although the spatial extent of the mobilization of energy may be limited (Meesters et al. 1994). Regeneration competes with other biological processes such as growth, reproduction, mucus production and competition (Meesters et al. 1994, Ward 1995, Rinkevich 1996, KramarskyWinter \& Loya 2000, Titlyanov et al. 2005). Lesion regeneration typically begins with the inward progression of undifferentiated tissue created by the polyps and coenenchyme surrounding the lesion, followed by the appearance of new polyps (Bak et al. 1977). Reduction in lesion size has been described using a negative exponential curve (Bak 1983, Meesters et al. 1992, Meesters \& Bak 1993, van Woesik 1998). However, the regeneration capacity of lesions varies with species (reviewed by Henry \& Hart 2005), colony characteristics (Kramarsky-Winter \& Loya 2000, Oren et al. 2001), lesion size and shape (Meesters et al. 1997, Oren et al. 1997b, van Woesik 1998) and environmental conditions (Fisher et al. 2007). Incomplete lesion regeneration is characteristic for massive corals (Meesters et al. 1994, 1997, Fisher et al. 2007). Therefore, an asymptote has been included in many regeneration models. Stressful environmental conditions that negatively affect the holobiont physiological state (Fisher et al. 2007), and hence the quantity of energy that the coral can allocate to regeneration, have been shown to decrease the regeneration capacity of corals (Lester \& Bak 1985, Titlyanov et al. 2005). Under prolonged stress, recovery may be impeded and supplanted by progressive necrosis, leading to permanent partial mortality or worse, total mortality of the coral colony (Meesters et al. 1994). Consequently, deviations from typical curve descriptors have been used to assess colony condition and environmental quality (Ginsburg et al. 2001, Fisher et al. 2007).

The current study was designed to evaluate the regeneration capacity of lesions on the massive scleractinian coral Porites lutea Milne-Edwards and Haime 1860. The role of extrinsic factors was analysed by monitoring colonies in different environmental settings and seasons. Intrinsic effects on capacity to regenerate lesions were minimized by creating artificial lesions of standard size and shape. P. lutea was selected because, like other massive species of this genus, it will probably remain an important member of coral communities affected by global change during coming decades (Hoegh-Guldberg et al. 2007). Currently, it is a major reef-building coral at Réunion Island (Guillaume 1988, Bruggemann et al. 2008). Moreover, previous studies of lesion regeneration provide comparative data (van Woesik 1998, Titlyanov et al. 2005, Titlyanov \& Titlyanova 2009).

\section{MATERIALS AND METHODS}

Study sites and environmental setting. The study was conducted from June 2007 to November 2008 at Réunion Island $\left(21^{\circ} 07^{\prime} \mathrm{S}, 55^{\circ} 32^{\prime} \mathrm{E}\right)$, a tropical high volcanic island located in the south-western Indian Ocean (Fig. 1a,b). Experiments were conducted in situ on shallow subtidal reef flats (1 to $2 \mathrm{~m}$ depth) at 4 different sites: Planch'Alizé and Trou d'Eau at la Saline reef, and Varangue and Kiosque at Saint-Leu reef. La Saline reef is the most extensive of the 4 reef complexes at Réunion Island, with the reef flat extending 350 to $550 \mathrm{~m}$ from shore over $9 \mathrm{~km}$ length (Fig. 1c). Benthic surveys (Naim 2006, Bruggemann et al. 2008) showed a relatively low coral diversity at la Saline, while at Planch'Alizé a large proportion of dead corals was covered by macroalgae. At Saint-Leu the reef flat is $5.7 \mathrm{~km}$ long and 200 to $250 \mathrm{~m}$ wide (Fig. 1d), with coral communities that have shown high resilience to disturbance (Scopélitis et al. 2009). Varangue is located near 2 river gullies (Fig. 1d) and is subject to terrigenous input, mainly during the hot, rainy season (Naim et al. 1997). Kiosque is exposed to strong wave action and has a constant influx of coastal water. This site presents the highest coral diversity known from Réunion (Bruggemann et al. 2008).

Seawater temperature (sea surface temperature, SST) was measured in situ at each site at hourly intervals using calibrated underwater temperature loggers (Hobo Water Temp Pro, accuracy: $0.2^{\circ} \mathrm{C}$, Onset Computer Corporation). SSTs were highest from January to April and lowest from July to October (Fig. 2a-d). Planch'Alizé (Fig. 2a) had the highest SSTs, ranging from $29.0^{\circ} \mathrm{C}$ in February 2007 to $23.5^{\circ} \mathrm{C}$ in August 2008 , and highest SST variation (SD of monthly means $>0.8^{\circ} \mathrm{C}$ ). Mean daily maxima varied from $30.5^{\circ} \mathrm{C}$ in the hot season (February 2007) to $25.0^{\circ} \mathrm{C}$ in the cool season (July 2008), with a highest temperature of $32.7^{\circ} \mathrm{C}$ recorded in February 2007. At Kiosque (Fig. 2d), SST ranged from $27.5^{\circ} \mathrm{C}$ in the hot season (January 2008) to $23.2^{\circ} \mathrm{C}$ in the cool season (August 2008) with the lowest SST variation compared to Planch'Alizé (SD of monthly means $<0.8^{\circ} \mathrm{C}$ ). Mean daily maxima ranged from $27.9^{\circ} \mathrm{C}$ in the hot season to $23.6^{\circ} \mathrm{C}$ in the cool season, with a highest recorded temperature of $29.1^{\circ} \mathrm{C}$. Temperature characteristics of Trou d'Eau (Fig. 2b) 


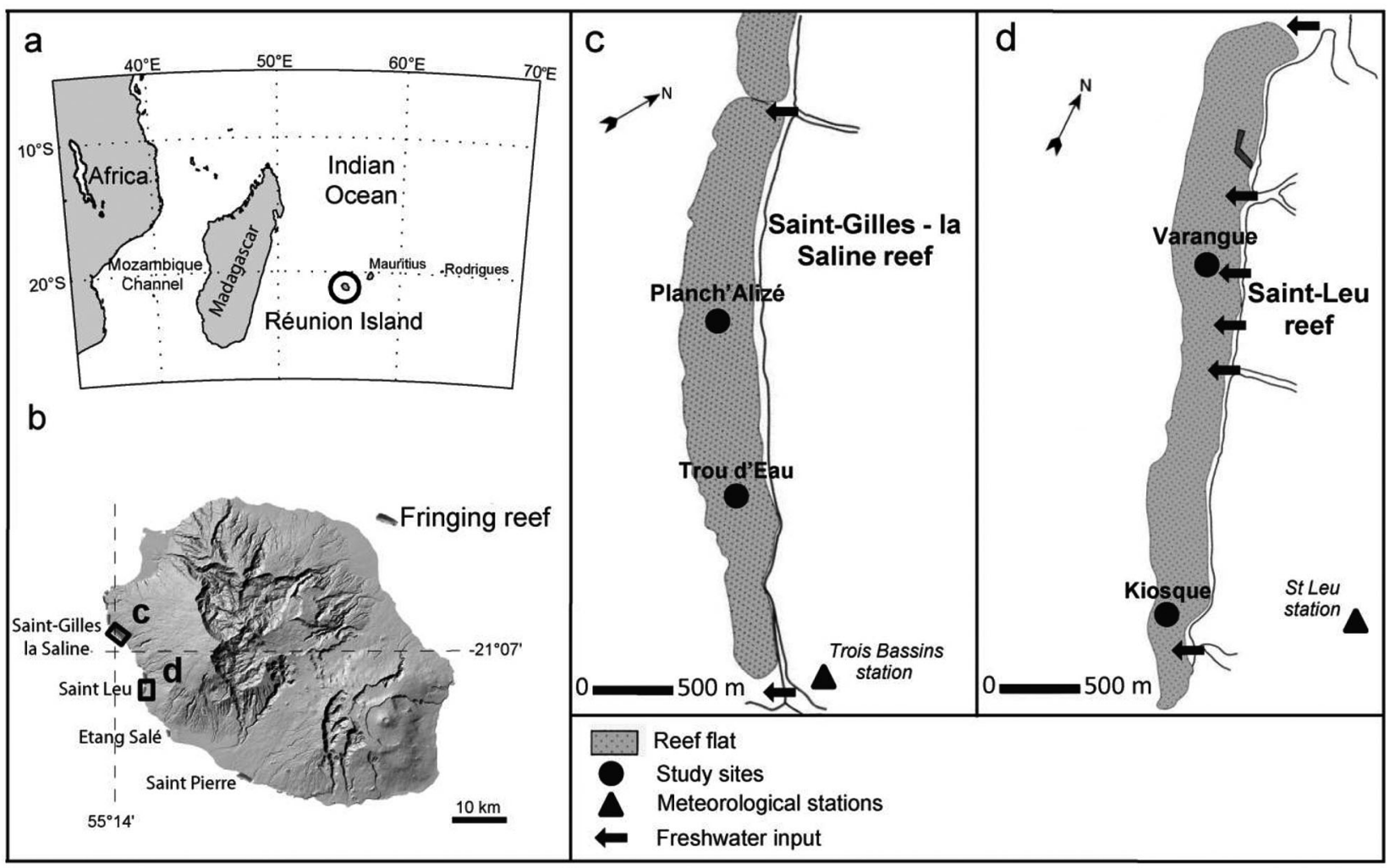

Fig. 1. (a) Réunion Island in the south-western Indian Ocean. (b) The 2 reef complexes studied. Study sites at (c) la Saline reef and (d) Saint-Leu reef

and Varangue (Fig. 2c) were intermediate between these extremes, with slightly higher temperatures at the former site.

Water flow is considered proportional to the weight loss of 'clod cards' ( $\mathrm{g} \mathrm{d}^{-1}$; Doty 1971). It was estimated using 10 replicate clod cards made of plaster of Paris (calcium sulfate), prepared as described by McClanahan et al. (2005), deployed simultaneously at each study site in December 2007 (hot season) and collected after $24 \mathrm{~h}$. Water flow differed significantly between sites (analysis of variance, ANOVA, $F=324.9, \mathrm{p}<0.01$; Fig. 2e). Highest clod dissolution rates were recorded at the Saint-Leu reef sites (Kiosque: $27.6 \pm 2.3 \mathrm{~g} \mathrm{~d}^{-1}$; Varangue: $17.8 \pm 2.1 \mathrm{~g} \mathrm{~d}^{-1}$ ). Water flow at both la Saline reef sites was much lower (Trou d'Eau: $4.8 \pm 1.7 \mathrm{~g} \mathrm{~d}^{-1}$; Planch'Alizé: $7.0 \pm 1.2 \mathrm{~g} \mathrm{~d}^{-1}$ ).

Cumulated daily global radiation $\left(\mathrm{J} \mathrm{cm}^{-2}\right)$ and monthly precipitation data were obtained from the French meteorological service from the station TroisBassins (no. 97415590), located at sea level near la Saline reef, and station Saint-Leu (no. 97413545), located above Saint-Leu reef at $205 \mathrm{~m}$ altitude (Fig. 1c,d). Monthly means of daily cumulated radiation were highest in the warming season (November to December, Table 1) and decreased during the hot season, especially during months with high rainfall. Low- est radiation occurred during the cooling and early cool seasons (June to July). Due to the formation of clouds along the steep slopes above Saint-Leu, daily cumulated radiation is lower here than at Trois-Bassins during the warming and hot seasons. During the coolest months, radiation values were similar for both reef complexes $\left(\sim 1400 \mathrm{~J} \mathrm{~cm}^{-2}\right)$. Seasonal precipitation was characteristic of a tropical climate with alternating wet and dry seasons (Table 1). High rainfall occurs mainly during the hot season, with peaks recorded in February 2007 and 2008 at Saint-Leu.

Lesion regeneration. Artificial lesions were inflicted seasonally (Fig. 2a-d) on the top of hemispherical coral colonies of Porites lutea (mean \pm SD colony diameter: $0.68 \pm 0.22 \mathrm{~m}, \mathrm{n}=70$ ), in July 2007 (cool season), November 2007 (warming season), January 2008 (hot season) and May 2008 (cooling season). In July 2007, lesion regeneration was assessed on 25 colonies selected haphazardly at Planch'Alizé and Kiosque. After analysis of this first data set, the number of colonies monitored during subsequent seasons was reduced to 10 , and experiments expanded to the sites Trou d'Eau and Varangue. Lesions were made using a grinding stone (Dremel no. 8193) powered by a pneumatic drill, creating circular lesions of $20.5 \pm 1.5 \mathrm{~mm}(\mathrm{n}=170)$ diameter. Lesion depth was set at $3 \mathrm{~mm}$, which left no visible 

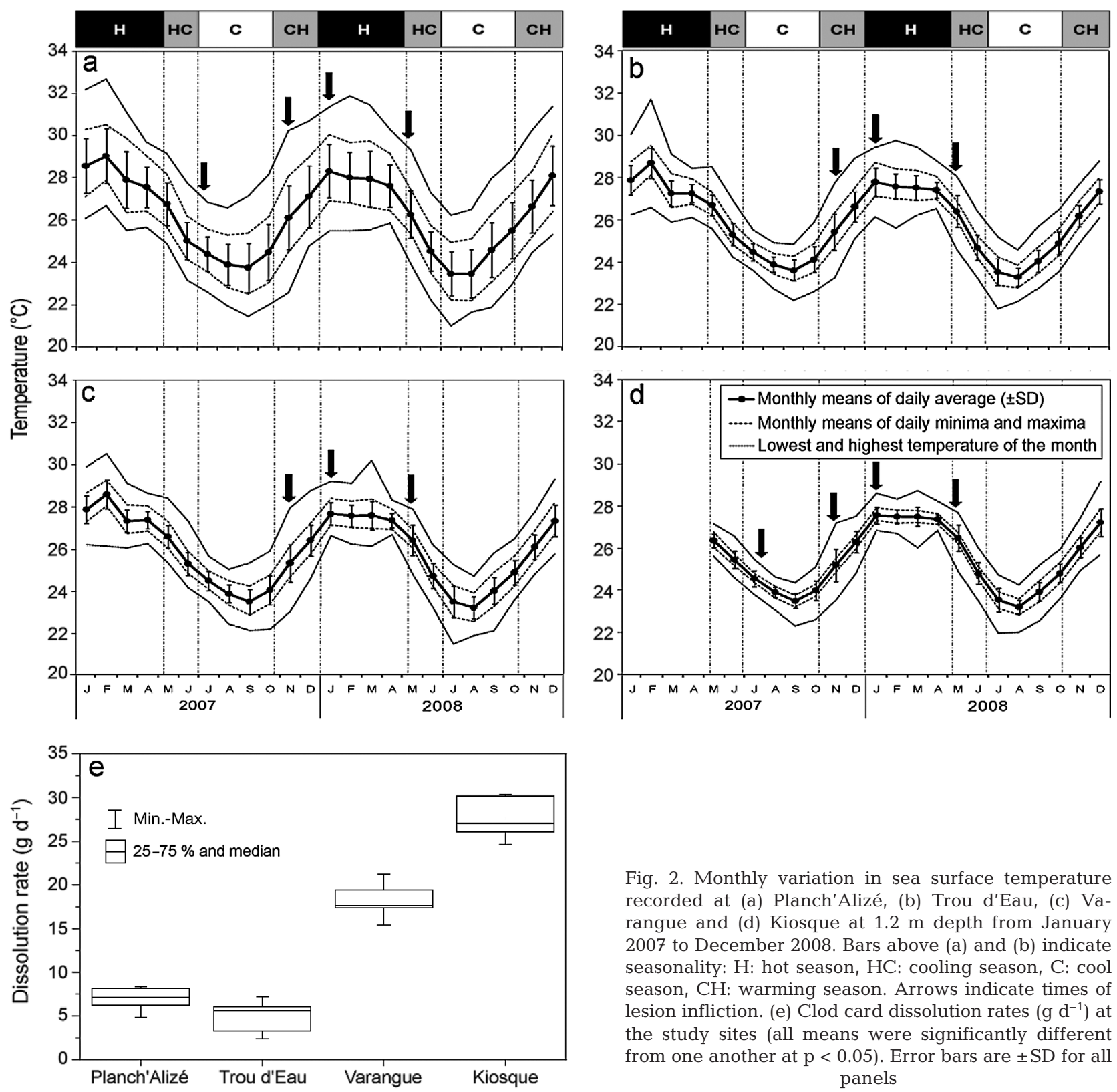

traces of remaining coral tissue inside the lesions. Lesion regeneration was monitored by taking digital photographs at a fixed distance, including a scale to calibrate measurements. Monitoring frequency was adapted to the rate of regeneration, ranging from daily shortly after lesion induction, to $3 \mathrm{wk}$ intervals. Regeneration was monitored during at least $150 \mathrm{~d}$ and until no significant change in lesion size was detected. Surface area of lesions was quantified from photographs using CPCe software (Kohler \& Gill 2006).

Initial lesion size was defined as the maximum size of the lesion before first signs of regeneration and was fixed at $100 \%$. Regeneration was quantified as the pro-

Fig. 2. Monthly variation in sea surface temperature recorded at (a) Planch'Alizé, (b) Trou d'Eau, (c) Varangue and (d) Kiosque at $1.2 \mathrm{~m}$ depth from January 2007 to December 2008. Bars above (a) and (b) indicate seasonality: H: hot season, HC: cooling season, C: cool season, $\mathrm{CH}$ : warming season. Arrows indicate times of lesion infliction. (e) Clod card dissolution rates $\left(\mathrm{g} \mathrm{d}^{-1}\right)$ at the study sites (all means were significantly different from one another at $p<0.05$ ). Error bars are \pm SD for all panels

portion recovered of the initial lesion area versus time (Nagelkerken \& Bak 1998). For each lesion, leastsquares regressions were used to fit an exponential decay model with an asymptote (Meesters et al. 1994, 1997, Fisher et al. 2007), as lesions were often not completely closed:

$$
\text { Size }=\text { Asymptote }+\left[\text { Size }_{\text {reg }} \times \mathrm{e}^{(- \text {Slope } \times t)}\right]
$$

where Size $=$ lesion surface; Asymptote $=$ the area not regenerated after regeneration ceased; Size $_{\text {reg }}=$ the maximum area that can be fully regenerated; Slope $=$ regression slope; $t=$ time in days. Regeneration rate can be determined using the differential equation: 
Table 1. Monthly means of daily cumulated global radiation and monthly total rainfall from January 2007 to December 2008 at Trois-Bassins (near la Saline, 5 m altitude) and SaintLeu (205 $\mathrm{m}$ altitude), Réunion Island

\begin{tabular}{|c|c|c|c|c|c|}
\hline \multirow{2}{*}{ Year } & \multirow{2}{*}{ Month } & \multirow{2}{*}{$\begin{array}{c}\text { Radiation } \\
\text { Trois- } \\
\text { Bassins }\end{array}$} & \multirow{2}{*}{$\begin{array}{c}\left(\mathrm{J} \mathrm{cm}^{-2}\right) \\
\text { Saint- } \\
\text { Leu }\end{array}$} & \multicolumn{2}{|c|}{ Rainfall (mm) } \\
\hline & & & & $\begin{array}{c}\text { Trois- } \\
\text { Bassins }\end{array}$ & $\begin{array}{l}\text { Saint- } \\
\text { Leu }\end{array}$ \\
\hline \multirow[t]{12}{*}{2007} & January & 2045 & 1845 & 25 & 32 \\
\hline & February & 2041 & 1703 & 147 & 277 \\
\hline & March & 2171 & 1835 & 17 & 30 \\
\hline & April & 1703 & 1468 & 19 & 5 \\
\hline & May & 1618 & 1523 & 3 & 4 \\
\hline & June & 1430 & 1420 & 6 & 19 \\
\hline & July & 1401 & 1370 & 56 & 103 \\
\hline & August & 1716 & 1580 & 9 & 7 \\
\hline & September & 1967 & 1799 & 3 & 15 \\
\hline & October & 2117 & 1838 & 40 & 40 \\
\hline & November & 2433 & 1985 & 0 & 5 \\
\hline & December & 2351 & 2103 & 162 & 116 \\
\hline \multirow[t]{12}{*}{2008} & January & 2192 & 1847 & 174 & 137 \\
\hline & February & 2031 & 1707 & 127 & 199 \\
\hline & March & 2111 & 1943 & 95 & 100 \\
\hline & April & 1685 & 1548 & 19 & 50 \\
\hline & May & 1563 & 1544 & 56 & 55 \\
\hline & June & 1347 & 1404 & 42 & 88 \\
\hline & July & 1494 & 1539 & 0 & 1 \\
\hline & August & 1787 & 1654 & 9 & 4 \\
\hline & September & 1891 & 1651 & 10 & 26 \\
\hline & October & 1949 & 1802 & 7 & 19 \\
\hline & November & 2137 & 1777 & 3 & 35 \\
\hline & December & 2524 & 2209 & 11 & 9 \\
\hline
\end{tabular}

$$
\mathrm{d}(\text { Size }- \text { Asymptote }) / \mathrm{d} t=
$$$$
-(\text { Size }- \text { Asymptote }) \times \text { Slope }
$$

Lesion size decreases exponentially over time as does the regeneration rate, which is a function of remaining lesion size. Therefore, the initial regeneration rate, also called maximum regeneration rate, was calculated at time 0 , just after lesion infliction.

Statistical analysis. Normality and homogeneity of the data were checked visually using residual plots. As different scales of transformation failed to meet parametric assumptions, differences in initial lesion size between sites and seasons were tested using the nonparametric Kruskal-Wallis (KW) analysis of variance followed by multiple pairwise comparisons.

$\mathrm{R}^{2}$ represents the proportion of the variance explained by the lesion regeneration model. Model fit was compared by season and by site using $\mathrm{R}^{2}$ values calculated for each lesion. Season and site effects on model estimates (slope, asymptote, initial regeneration rate) were analysed using parameters estimated for each lesion. Lesion regeneration parameters obtained from different colonies were considered as independent variables, whereas those obtained from the same colony in different seasons were treated as dependent variables. Colony size and initial lesion size were taken as co-variables in analyses of covariance (ANCOVA), with sites and seasons as factors, to test their potential effects on lesion regeneration parameters.

When parametric assumptions were met, differences in model parameters between sites were tested using analysis of variance (ANOVA), while season effects alone, or season and site effects combined, were tested using repeated measures ANOVA (RMA), using when necessary the Greenhouse-Geisser correction to accommodate violation of sphericity assumption (Stevens 2002). We used $t$-tests and Fisher least significant difference (LSD) post hoc comparisons to interpret effects detected by ANOVA. When parametric assumptions could not be met, untransformed data (Sokal \& Rohlf 1995) were analysed using KW to test season and site effects separately and combined with the ScheirerRay-Hare extension (SRH) to test season and site effects simultaneously. Combinations of variables that best predicted the regeneration parameters were examined using forward stepwise least-squares multiple regressions procedures (Sokal \& Rohlf 1995). Values of environmental parameters were averaged over various time periods following lesion infliction (day, week, fortnight, month and total monitored lesion regeneration period) and correlated to model estimates. Best fits were obtained using monthly means of daily average water temperature, monthly means of daily cumulative solar radiation and monthly cumulated rainfall; these values were used in regression analysis. Absence of multicollinearity between variables was assessed first using pairwise correlation, then by examining the variance inflation factor (VIF) values. All statistical analyses were performed using Statistica 6.1 (StatSoft).

\section{RESULTS}

\section{Onset and progression of lesion regeneration}

In total, > 2500 photographs were analysed to monitor the healing process of 170 lesions. During the first hours after removing coral tissue, fishes and hermit crabs cleaned the lesions by eating dead tissue at the edges. Thus, during the first day, lesion size increased slightly due to mortality of surrounding polyps. Lesion regeneration was manifest from the second day onwards by the rapid decrease of the lesion size (Fig. 3). Regeneration from within lesions was not observed. During the first weeks of the regeneration process, healing edges presented a conspicuous pale colour; these recovered pigmentation similar to that of the rest of the colony, after this period of intense regeneration (Fig. 4a). Often, and 


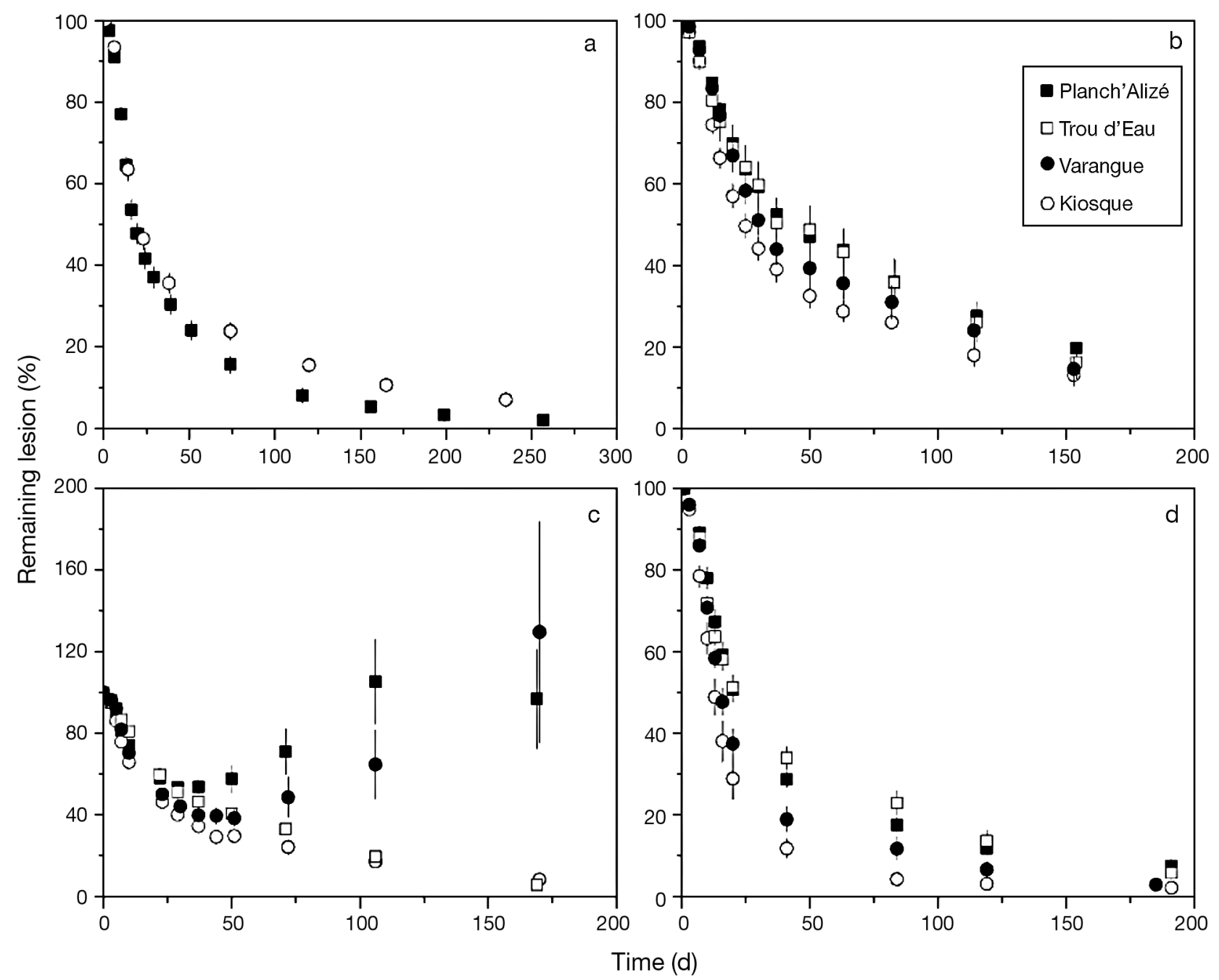

Fig. 3. Porites lutea. Change in lesion size as $\%$ of original lesion size over time (mean \pm SE) at the different reef sites in the (a) cool season, (b) warming season, (c) hot season and (d) cooling season. Note differences in the scales of the (a) $x$-axis and (c) $y$-axis; no cool season data were available for Trou d'Eau and Varangue

in particular for degenerating lesions, a bright pink lesion margin was observed (Fig. 4b).

Initial lesion size was $330 \pm 50 \mathrm{~mm}^{2}$ (mean $\pm \mathrm{SD}, \mathrm{n}=$ 170). Despite efforts to inflict similar sized lesions, initial lesion sizes at Varangue were slightly higher for the warming season $\left(390 \pm 40 \mathrm{~mm}^{2}, \mathrm{n}=10, \mathrm{KW}, H=35.3, \mathrm{p}<\right.$ 0.001) than for other sites and seasons. Differences in initial lesion size did not affect lesion regeneration parameters (ANCOVA, regression slope: $F=0.13, \mathrm{p}=0.72$; asymptote: $F=1.93, \mathrm{p}=0.17$; initial regeneration rate: $F=$ $0.68, \mathrm{p}=0.41$ ). Similarly, no effect of coral colony size on lesion regeneration was detected (ANCOVA, regression slope: $F=1.62, \mathrm{p}=0.20$; asymptote: $F=1.07$, $\mathrm{p}=0.30$; initial regeneration rate: $F=0.68, \mathrm{p}=0.41$ ).

Overall, only $18 \%$ of the inflicted lesions healed completely within 6 to 9 mo. Lesion degeneration, defined as progressively increasing lesion size, oc- curred only at Planch'Alizé and Varangue during the hot season, affecting 57 and $46 \%$ of the lesions, respectively (Figs. 3c, 4b).

\section{Parameter estimates}

The temporal evolution of lesion size generally followed an exponential decay curve to an asymptote (Fig. 3). Coefficients of determination $\left(\mathrm{R}^{2}\right)$ of the negative decay model were mostly high (Table 2), attesting the accuracy of the model for describing regeneration in Porites lutea. Both site and season affected model fits ( $\mathrm{SRH}, H=16.12, \mathrm{p}<0.05)$ : $\mathrm{R}^{2}$ values were significantly lower during the hot season at Planch'Alizé (0.62) and Varangue (0.68), the 2 sites where degeneration of lesions was observed. 


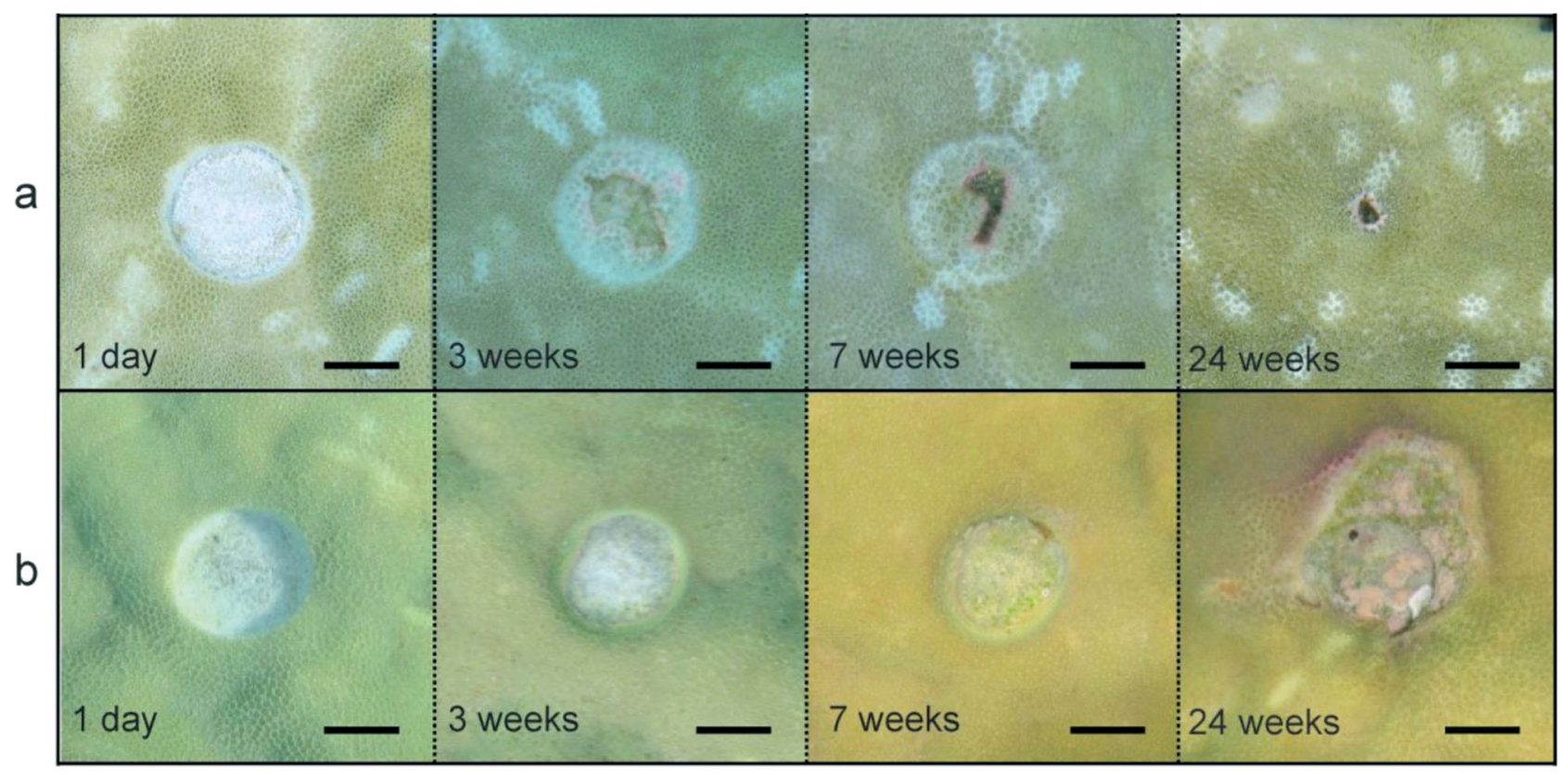

Fig. 4. Porites lutea. Contrasting lesion regeneration patterns at Planch'Alizé. (a) Lesion inflicted in July 2007, almost completely healed; (b) lesion inflicted in January 2008, increasing in size. Note the pink margin around the degenerating lesion (with photographs at 7 and $24 \mathrm{wk}$ taken at night). Scale bar $=10 \mathrm{~mm}$

Table 2. Mean $\mathrm{R}^{2}$ values $( \pm \mathrm{SE}$ ) by site and season of the lesion regeneration curve (Eq. 1). Bold type indicates significant low values $(\mathrm{p}<0.05)$

\begin{tabular}{|lccccc|}
\hline Season & Planch'Alizé & $\begin{array}{c}\text { Trou } \\
\text { d'Eau }\end{array}$ & Varangue & Kiosque & $\begin{array}{c}\text { Overall } \\
\text { mean }\end{array}$ \\
\hline Cool season & $0.98(0.00)$ & - & - & $0.98(0.00)$ & $0.98(0.00)$ \\
Warming season & $0.98(0.00)$ & $0.98(0.00)$ & $0.97(0.00)$ & $0.98(0.00)$ & $0.98(0.00)$ \\
Hot season & $\mathbf{0 . 6 2 ( 0 . 1 1 )}$ & $0.98(0.01)$ & $\mathbf{0 . 6 8}(\mathbf{0 . 1 0})$ & $0.98(0.01)$ & $0.80(0.05)$ \\
Cooling season & $0.98(0.00)$ & $0.97(0.01)$ & $0.97(0.00)$ & $0.97(0.00)$ & $0.97(0.00)$ \\
Overall mean & $0.90(0.03)$ & $0.98(0.02)$ & $0.87(0.04)$ & $0.98(0.02)$ & $0.93(0.01)$ \\
\hline
\end{tabular}

\section{Regression slope}

The rate of regeneration is reflected by the regression slope. Slopes ranged from $0.023 \mathrm{~d}^{-1}$ (Planch'Alizé and Trou d'Eau, warming season) to $0.062 \mathrm{~d}^{-1}$ (Kiosque, cooling season; Fig. 5a). Both season

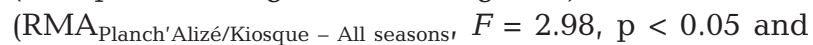
$\mathrm{RMA}_{\text {All sites - Warming/Hot/Cooling, }} F=12.93, \mathrm{p}<0.001$ ) and site $\left(\mathrm{RMA}_{\text {Planch'Alizé/Kiosque - All seasons, }} F=5.26, \mathrm{p}<0.05\right.$;

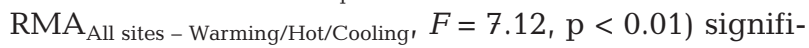
cantly affected slopes. Overall, regression slopes showed significant season effects (RMA, $F=16.84, \mathrm{p}<$ 0.001 ), with lowest mean slopes during the warming season and highest during the cooling season, and no significant difference in slopes between the cool and hot seasons (inset of Fig. 5a).

For each site separately, season significantly affected the slopes (RMA with post hoc comparisons, Fig. 5a).
At Planch'Alizé, curve slopes decreased from cool $\left(0.038 \mathrm{~d}^{-1}\right)$ to warming seasons $\left(0.023 \mathrm{~d}^{-1}\right)$, followed by an increase in the hot season $\left(0.039 \mathrm{~d}^{-1}\right)$ with slopes attaining similar values as recorded in the cool season $(p=0.89)$. Similarly, curve slopes at Varangue were lowest in the warming season $\left(0.027 \mathrm{~d}^{-1}\right)$ and highest in the hot season $\left(0.054 \mathrm{~d}^{-1}\right)$. At Trou $\mathrm{d}^{\prime}$ Eau and Kiosque, slopes increased gradually from lowest values in the warming season (Trou d'Eau: $0.023 \mathrm{~d}^{-1}$; Kiosque: $0.036 \mathrm{~d}^{-1}$ ) to highest in the cooling season (Trou d'Eau: $0.040 \mathrm{~d}^{-1}$; Kiosque: $0.062 \mathrm{~d}^{-1}$ ).

In the cool season, site comparisons did not reveal significant differences in slopes between Planch'Alizé and Kiosque (1-way ANOVA with post hoc comparisons, $F=0.06, p=0.65$, see brackets above bars in Fig. 5a). In the warming season, slopes were significantly higher at Kiosque than at both la Saline reef sites (ANOVA, $F=3.69$, p < 0.05). Planch'Alizé had the lowest slopes, but these did not differ significantly from mean slopes at Trou d'Eau and Varangue, sites which had intermediate values. During the hot season, curve slopes were highest at Varangue, while slopes at Trou d'Eau were significantly lower than those of the other sites (ANOVA, $F=7.68, \mathrm{p}<0.001$ ). In the cooling season, Kiosque presented higher slopes than the 3 other sites (ANOVA, $F=6.08, \mathrm{p}<0.01$ ). 

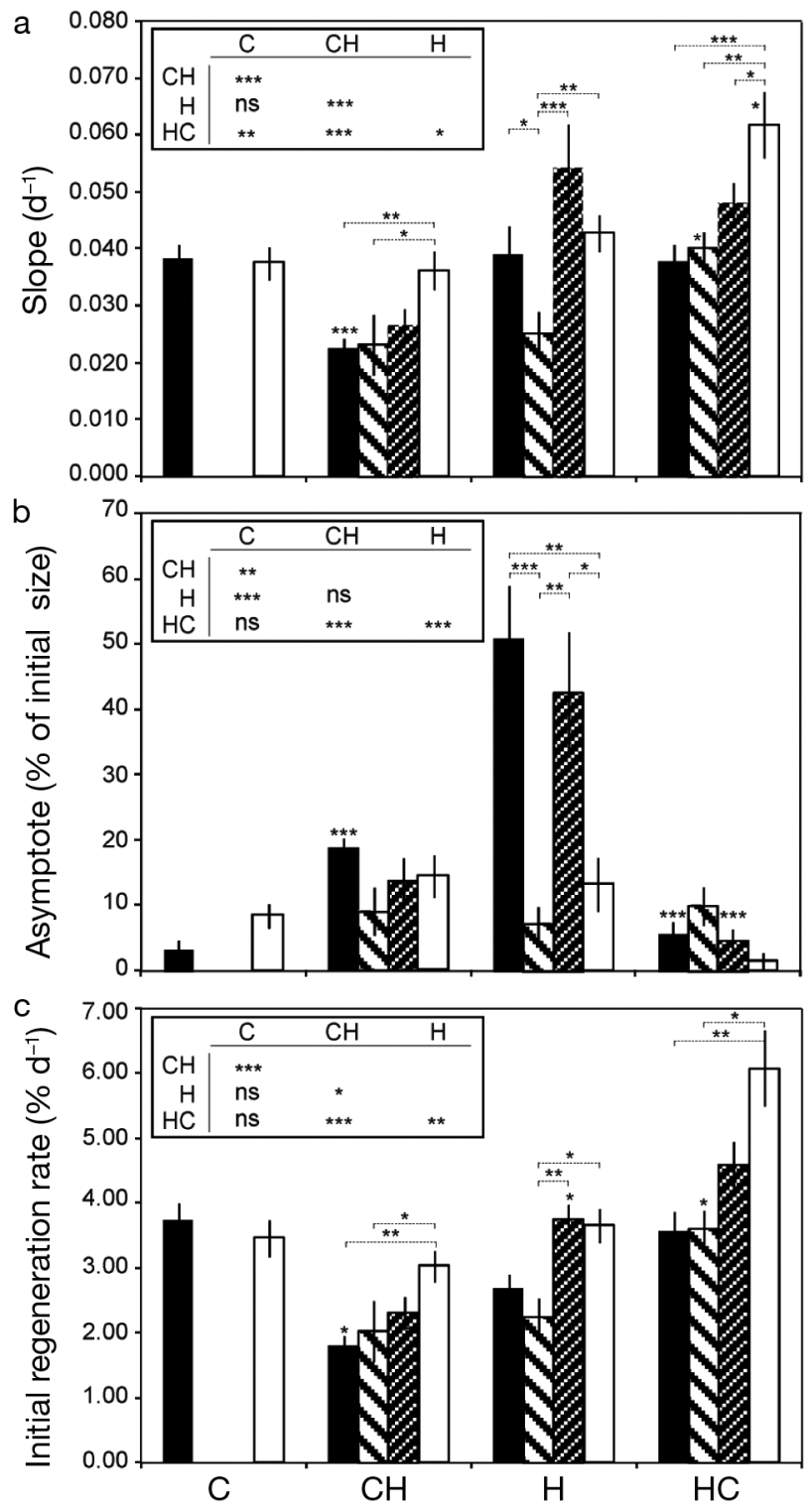

\section{Planch'Alizé 1 Trou d'Eau Varangue $\square$ Kiosque}

Fig. 5. Porites lutea. Regeneration curve parameters by season and site. (a) Slopes, (b) asymptotes, (c) initial regeneration rates. Inset tables represent overall mean comparison by season. Asterisks above bars indicate the level of significant change for each site compared to the previous season. Brackets with asterisks above bars indicate, for each season, the level of significant difference between sites. Errors bars represent SE. ${ }^{* * *} p<0.001,{ }^{* *} p<0.01$ and ${ }^{*} p<0.05$; ns: not significant. See Fig. 2 for season abbreviations

\section{Asymptote}

The asymptote level indicates the remaining unhealed lesion area (\% of initial lesion size) after regeneration ceased. Asymptotes were also strongly affected by sites and seasons (Site effect: $\mathrm{SRH}_{\text {Planch'Alizé/Kiosque - All }}$ seasons' $H=9.76, \mathrm{p}<0.01$ and $\mathrm{SRH}_{\text {All sites }- \text { Warming/Hot/Cooling' }}$ $H=35.81, \mathrm{p}<0.001$, season effect: $\mathrm{SRH}_{\text {Planch'Alizé/Kiosque }}$ - All seasons, $H=61.90, \mathrm{p}<0.001$ and $\mathrm{SRH}_{\text {All sites - }}$ Warming/Hot/Cooling, $H=79.12, \mathrm{p}<0.001)$. Overall, asymptotes were higher in the warming and hot seasons than in the cooling and cool seasons (KW, H=39.5, p < 0.001, inset Fig. 5b).

For each site, season comparisons revealed significantly higher asymptotes at Planch'Alizé (51.0\%) and at Varangue (39.2\%) during the hot season (see asterisks above bars in Fig. 5b) than during the other seasons. For the other 2 sites, no season effects on asymptotes were detected.

For each season, site comparisons showed significant differences only in the hot season (KW, $H=23.12$, p < 0.001, see brackets above bars in Fig. 5b). Two groups were distinguished: Planch'Alizé and Varangue both had high asymptotes and high variance (standard error, $\mathrm{SE}_{\text {Planch'Alizé }}=8.0 \%$ and $\mathrm{SE}_{\text {Varangue }}=9.1 \%$ ), contrasting with Trou d'Eau and Kiosque with low asymptotes and variance $\left(\mathrm{SE}_{\text {Trou d'Eau }}=2.7 \%\right.$ and $\mathrm{SE}_{\text {Kiosque }}=$ $4.0 \%$; Fig. 5b).

\section{Initial regeneration rate}

Initial regeneration rates varied with season ( $\mathrm{SRH}_{\text {Planch'Alizé/Kiosque - All seasons' }} H=61.48, \mathrm{p}<0.001$ and $\mathrm{SRH}_{\text {All sites - Warming/Hot/Cooling, } H=84.24, \mathrm{p}<0.001) \text { and }}$ site $\left(\mathrm{SRH}_{\text {Planch'Alizé/Kiosque - All seasons }} H=38.21, \mathrm{p}<0.001\right.$;

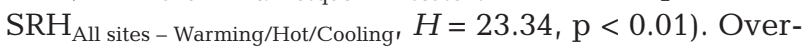
all, initial regeneration rates decreased from the cool to the warming season, followed by an increase during the hot season to maximum values in the cooling season (inset Fig. 5c).

For each site, season comparisons showed gradual changes between subsequent seasons (Fig. 5c). For the warming and cooling seasons, Planch'Alizé and Kiosque represented 2 extremes in the initial regeneration rates, with highest rates recorded at the latter site (Fig. 5c). Trou d'Eau and Varangue had intermediate initial regeneration rates. In the hot season, regeneration rates at Kiosque and Varangue were higher than those at Trou d'Eau.

Based on these initial regeneration rates and on the mean initial lesion size, maximum regeneration rates ranged from $6.0 \mathrm{~mm}^{2} \mathrm{~d}^{-1}$ at Planch'Alizé in the warming season to $20.1 \mathrm{~mm}^{2} \mathrm{~d}^{-1}$ at Kiosque in the cooling season.

\section{Environmental correlates}

Forward stepwise multiple regressions for predicting lesion regeneration slope and initial regeneration 


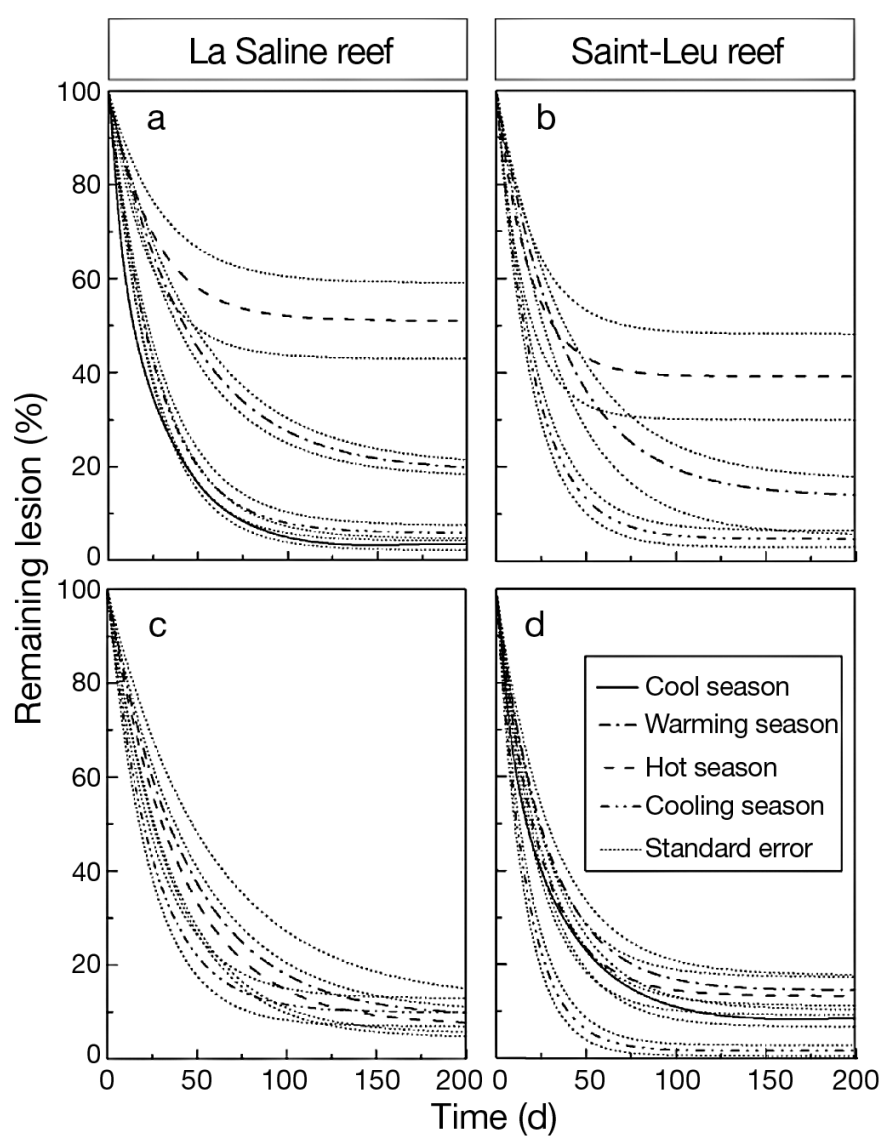

Fig. 6. Porites lutea. Prediction of the regeneration of lesions for the study sites using the model Size = Asymptote + $\left[\right.$ Size $\left._{\text {reg }} \times \mathrm{e}^{(- \text {Slope } \times t)}\right]$ (see Eq. 1 in text) with a lesion inflicted in $(\mathrm{a}, \mathrm{d}) 4$ different seasons or $(\mathrm{b}, \mathrm{c}) 3$ different seasons. (a) Planch'Alizé, (b) Varangue, (c) Trou d'Eau, (d) Kiosque

Table 3. Forward stepwise multiple regressions of slope, asymptote $\left(y_{0}\right)$ and initial regeneration rate with 4 environmental variables: seawater temperature, solar radiation, rainfall and water flow. Stepwise analysis determines the variables that best explain the variation in the respective lesion regeneration parameter. Selected variables were then used in the least squares multiple regression model

\begin{tabular}{|lrrrrr|}
\hline & $\begin{array}{c}\text { Beta } \\
\text { Coefficient }\end{array}$ & $\mathrm{p}$ & $\mathrm{R}^{2}$ & $F$ & $\begin{array}{c}\mathrm{p} \text {-value } \\
\text { regression }\end{array}$ \\
& & & & & \\
\hline Regression slope & & & 0.78 & 8.17 & $<0.01$ \\
$\quad$ Temperature & 0.81 & $<0.05$ & & & \\
Solar radiation & -0.80 & $<0.01$ & & & \\
$\quad$ Rainfall & -0.35 & 0.19 & & & \\
Water flow & 0.34 & 0.07 & & & \\
Asymptote & & & 0.32 & 5.90 & $<0.05$ \\
$\quad$ Temperature & 0.57 & $<0.05$ & & & \\
Initial regeneration rate & & & 0.80 & 9.13 & $<0.01$ \\
$\quad$ Temperature & 0.69 & $<0.05$ & & & \\
Solar radiation & -0.91 & $<0.001$ & & & \\
$\quad$ Rainfall & 0.27 & 0.09 & & & \\
Water flow & -0.46 & 0.12 & & & \\
\hline
\end{tabular}

rate retained all environmental variables which together explained $78 \%$ of the variation in slopes and $80 \%$ of the variation in initial regeneration rates (Table 3). However, of these parameters, only SST and radiation contributed significantly, explaining 63 and $65 \%$ of the variation, respectively. No interaction between SST and radiation was detected. Slopes and initial regeneration rates increased with SST, but decreased with increasing radiation. Asymptotes were affected only by SST, which accounted for $32 \%$ of the variation (Table 3 ). Residual lesion size increased with SST.

\section{Predicted lesion regeneration by site and season}

Temporal and spatial characteristics of slopes and asymptotes were used to simulate regeneration at each site for each season (Fig. 6). Planch'Alizé clearly showed a decrease in regeneration capacity from the cool to the warming and hot seasons before regaining high regenerative competence during the cooling season. A similar trend occurred at Varangue, but with better regeneration capacity in warming and hot seasons compared to the former site. Lesion regeneration at sites Trou d'Eau and Kiosque did not show strong seasonal variability. However, regeneration capacity was always better in the cooling season.

\section{DISCUSSION}

Following recommendations of previous studies (Fisher et al. 2007), confounding effects of initial lesion size and shape on lesion regeneration were avoided by inducing lesions of standard size and depth. The wide range of regenerative responses observed, from complete healing to degeneration, suggests that the size of artificial lesions used in this study $\left(\sim 330 \mathrm{~mm}^{2}\right)$ was well suited to examine lesion regeneration capacity in Porites lutea populations in different environmental settings. Generally, the temporal pattern of regeneration was described accurately by an exponential decay equation with an asymptote, as attested by the large and significant $\mathrm{R}^{2}$. While this model is not well suited to accommodate increases in lesion size (degeneration), its use has the benefit of facilitating comparisons with other studies. 


\section{Lesion healing in Porites Iutea: parameter comparisons}

Asymptote values vary with initial lesion size in massive corals, indicating that such corals have limited capacity for lesion regeneration (Meesters et al. 1997). Lesion regeneration in the massive coral Montastrea annularis was incomplete for lesions of sizes similar to those used in the present study (243 to $406 \mathrm{~mm}^{2}$ ), leaving unhealed patches representing 14 to $30 \%$ of initial lesion size (Meesters et al. 1997). While lesion regeneration capacity in massive Porites lutea at Réunion Island was also clearly limited (this study), asymptote values were generally lower (approximately 5 to $20 \%$ ), except during the hot season at Planch'Alizé and Varangue, where up to $50 \%$ of the initial lesion size was not regenerated after healing ceased. In contrast, $P$. lutea on the high-latitude reefs of Okinawa, Japan, were capable of complete lesion regeneration, in spite of the relatively large initial lesion sizes $\left(\leq 1310 \mathrm{~mm}^{2}\right.$, van Woesik 1998).

Regression slopes of lesion regeneration curves of Porites lutea at Réunion Island ranged from 0.023 to $0.062 \mathrm{~d}^{-1}$, higher than those of $P$. lutea and P. lobata at Okinawa $\left(0.013\right.$ to $0.019 \mathrm{~d}^{-1}$ and 0.014 to $0.018 \mathrm{~d}^{-1}$ respectively, van Woesik 1998), but within the range of values reported for massive (Montastrea annularis) and submassive ( $P$. astreoides) corals in the Caribbean (Meesters \& Bak 1993).

The high initial regeneration rate rapidly decreased lesion size, entraining an exponential decrease in regeneration rate (see Eq. 2). Calculated from the parameters given by van Woesik (1998) for lesion size similar to the one inflicted in the present study, initial regeneration rates for Porites lutea in Okinawa were somewhat lower than those in Réunion (respectively 0.4 to $17.0 \mathrm{~mm}^{2} \mathrm{~d}^{-1}$ and 6.0 to $20.1 \mathrm{~mm}^{2} \mathrm{~d}^{-1}$ ).

Several studies report mean daily regeneration rates, determined from the difference in lesion size across a period of time. Comparisons with such results are problematical because of the incorrect postulate of a constant regeneration rate. Nevertheless, we calculated a mean daily regeneration rate for Porites lutea, using similar time intervals and seasons as used by Titlyanov et al. (2005) and Titlyanov \& Titlyanova (2009) for documenting its regeneration capacity in Okinawa. Despite the very large lesions (up to around $25 \mathrm{~cm}^{2}$ ) used and the high (initial) regeneration rates that should be expected as a consequence (see Eq. 2), mean daily regeneration rates in $P$. lutea at Okinawa ( 0.01 to $0.22 \mathrm{~mm} \mathrm{~d}^{-1}$ ) were comparable to the regeneration rates recorded at Réunion Island (0.01 to $0.20 \mathrm{~mm} \mathrm{~d}^{-1}$ ). This further confirms the fast initial lesion regeneration in $P$. lutea at Réunion Island, in spite of limited capacity to heal lesions completely.
Regenerative abilities in the same species can thus differ markedly between localities, highlighting the importance of environmental factors.

\section{Season and site effects on lesion regeneration at Réunion Island}

Porites lutea showed seasonal and site variability in regeneration capacity. Lesion repair was best in the cooling and cool seasons. During the cooling season, when solar radiation was low but SSTs intermediate, lesion regeneration was characterised by highest slopes and highest initial regeneration rates. Asymptote values, influenced by temperature alone, were lowest during the cool season. This contrasted with the warming and hot seasons, when lesion regeneration properties exhibited lower slopes and initial regeneration rates and high asymptote values, correlated to the high solar radiation (warming season) and high temperatures (hot season). Comparable results were obtained in Okinawa where mean daily healing rates in $P$. lutea were higher during winter and lower during summer (Titlyanov et al. 2005). These observations contrast with the temperature effects on lesion regeneration observed in Fungia granulosa in the northern Red Sea. Field and laboratory experiments with this fungiid coral revealed faster and more complete lesion repair during the hotter months. However, intrinsic (gametogenesis) and extrinsic (algal blooms, sedimentation) factors may have contributed to the seasonal pattern observed at this site (Kramarsky-Winter \& Loya 2000).

Key life processes, such as reproduction, typically show seasonal patterns. Lower regenerative abilities recorded before spawning have been associated with the energy required for gametogenesis (KramarskyWinter \& Loya 2000). A chance observation of gamete release by several colonies of Porites lutea on 29 December 2007 at Planch'Alizé (V. Denis et al. unpubl. obs.) suggests that gamete maturation occurs during the warming season. Competition for energy allocation to reproduction versus regeneration may partially explain the lower regenerative abilities observed during this season.

Site variability in lesion regeneration properties has been used as an indicator of environmental conditions that affect coral health (Fisher at al. 2007). High and steady regeneration capacity of coral colonies at Kiosque may be related to the regular influx of coastal water onto the reef flat at this site (Fig. 2e). Source and flow speed of water masses control the opportunities that coral have for heterotrophic feeding (Sebens et al. 1998), which may represent an important additional energy source for zooxanthellate corals (Houlbrèque \& 
Ferrier-Pagès 2009), potentially boosting lesion regeneration (Nagelkerken \& Bak 1998).

Lesion regeneration capacity was poorest at Planch'Alizé and Varangue, the only sites where degeneration occurred during the hot season. Benthic communities at these sites are characterised by low coral diversity and a high cover of foliose macroalgae (Mioche \& Cuet 1999, Naim 2006, Bruggemann et al. 2008). While the high mean SST and high SST variance, especially during the hot season, combined with high solar radiation, may have impaired lesion regeneration capacity at Planch'Alizé (see section below), synergistic stressors may have contributed. At this site, the back-reef zone is chronically enriched with nutrients due to groundwater inputs; organic matter produced here spreads onto the reef flat, while nutrient recycling (Mioche \& Cuet 1999) may further contribute to algal development. Corals at Varangue, located in the vicinity of 2 river gullies, are probably submitted regularly to large amounts of land-derived sediments, in particular 1 mo after summer lesions were inflicted, due to heavy rains in February 2008 (Table 1). Previous studies have shown that sedimentation and algal settlement may represent important physical and/or chemical impediments to lesion regeneration (Meesters et al. 1992, Titlyanov et al. 2005, Titlyanov \& Titlyanova 2009). Chronic disturbance thus impairs the resilience capacity of corals (Connell 1997), contributing to the loss of coral cover at urbanized coastlines (Fisher et al. 2007), which is ongoing at Réunion Island (Bigot 2008).

\section{Effects of light and temperature on holobiont functioning and capacity for lesion repair}

The capacity of corals for lesion repair decreases when the supply of photosynthetic products from zooxanthellae is reduced, e.g. under light-limiting conditions (Titlyanov et al. 2005). We showed a negative effect of solar radiation on regression slopes and initial regeneration rates of lesions in Porites lutea. These observations may be explained by an inhibition of photosynthesis (Warner et al. 2002). A parallel study of the photosynthetic efficiency of zooxanthellae around the regenerating lesions studied here confirmed that high radiation decreased their photosynthetic yield (V. Denis unpubl.).

Lesion regeneration may be drastically impaired by coral bleaching (Meesters \& Bak 1993, Meesters et al. 1997, Fine et al. 2002). In the present study, lesions inflicted during the hot season coincided with a La Niña event (Levy 2009), resulting in lower summer temperatures than usual for this time of year. Notwithstanding the fresh summer and absence of coral blea- ching on Réunion reefs, lesion regeneration capacity in Porites lutea was generally lower during this season. It is therefore highly likely that during El Niño years with positive SST anomalies the capacity of $P$. lutea populations to repair damage will be seriously compromised at Réunion Island, especially during bleaching events.

Higher SSTs boost coral metabolism and increase skeletal growth rates (Lough \& Barnes 2000), but also increase the amount of energy required for maintenance. Slopes and initial regeneration rates of lesions in Porites lutea were positively correlated with SST. Temperature effects on regenerative rate, mediated by coral metabolism, have also been reported from the Red Sea (Kramarsky-Winter \& Loya 2000) and the Caribbean (Lester \& Bak 1985).

Higher SSTs were further correlated with increases in the lesion surface that was not healed. Although only $32 \%$ of the variation in asymptote values was accounted for by temperature, it may reflect a consequence of energy depletion due to high coral metabolism. Alternatively, environmental conditions prevailing during the hot season favour the development of benthic algae on reefs at Réunion (Naim 1993, V. Denis pers. obs.) and increase the competition between corals and algae (Bak \& Steward-van Es 1980, Titlyanov et al. 2005). While some algae may have allelopathic effects on corals (Rasher \& Hay 2010) and may hamper regeneration (Titlyanov \& Titlyanova 2008), no known allelopathic algal taxa were identified inside lesions. Furthermore, the photosynthetic efficiency of coral tissues at margins of regenerating lesions was not depressed (V. Denis unpubl.).

In conclusion, the capacity for lesion regeneration in Porites lutea is clearly related to light and temperature. These observations are best explained by the combined effects of variations in the supply of photosynthates by zooxanthellae, the metabolic rate of the coral host and its energy requirements for maintenance and other life processes. Monitoring in situ the photosynthetic efficiency of zooxanthellae during lesion regeneration may contribute to a better understanding of the mechanisms underlying the supply side of this vital process.

Site effects cannot be explained by the environmental parameters light and temperature alone; lesion repair capacity can thus be used as a simple indicator of chronic disturbances that undermine the regeneration capacity of corals.

Global climate change is expected to increase the frequency and severity of coral bleaching events over the next decades. As coral bleaching often results in partial colony mortality, identifying the environmental conditions that compromise the resilience capacity of coral populations assists in focusing management efforts aiming to preserve coral reefs. 
Acknowledgements. The PhD fellowship to V.D. and research grant to J.H.B. and M.M.M.G. (ITUE program) provided by Regional Council of Réunion Island are gratefully acknowledged. Research was conducted with permission of the regional authorities of marine affairs and the marine park authorities (RNNMR). We thank A. Delval, J. K. L. Leung, P. Pinet, C. Simon, A. Valery and M. Wilhem for field assistance and L. Bigot, P. Cuet and J. Kolasinski for helpful comments on this manuscript. Meteo France kindly provided solar radiation and rainfall data.

\section{LITERATURE CITED}

Bak RPM (1983) Neoplasia, regeneration and growth in the reef-building coral Acropora palmata. Mar Biol 77: 221-227

Bak RPM, Steward-van Es Y (1980) Regeneration of superficial damage in the scleractinian corals Agaricia agaricites f. purpurea and Porites astreoides. Bull Mar Sci 30: 883-887

Bak RPM, Brouns J, Heys FML (1977) Regeneration and aspects of spatial competition in the scleractinian corals Agaricia agaricites and Montastrea annularis. Proc 3rd Int Coral Reef Symp 1:143-148

Bigot L (2008) Evolution spatio-temporelle de la biodiversité et de la structure des communautés benthiques entre 1998 et 2008 sur les stations sentinelles GCRMN de la Réunion. Rapport UR/APMR

Bruggemann $\mathrm{H}$, Guillaume $\mathrm{M}$, Bigot L, Chabanet $\mathrm{P}$ and others (2008) Mise en œuvre de l'effet réserve: développement des protocoles et établissement de l'état initial de la Réserve Naturelle Nationale Marine de la Réunion (secteurs de la Saline-Souris Blanche et de Saint-Leu). Rapport UR/MNHN/AR/APMR

Bythell JC, Gladfelter EH, Bythell M (1993) Chronic and catastrophic natural mortality of three common Caribbean reef corals. Coral Reefs 12:143-152

Connell JH (1997) Disturbance and recovery of coral assemblages. Coral Reefs 16:S101-S113

DeVantier LM, Done TJ (2007) Inferring past outbreaks of crown-of-thorns seastar from scar patterns on coral heads. In: Aronson RB (ed) Geological approaches to coral reef ecology. Springer, New York, NY

Diaz-Pulido G, McCook LJ, Dove S, Berkelmans R and others (2009) Doom and boom on a resilient reef: climate change, algal overgrowth and coral recovery. PLoS ONE 4:e5239

Doty MS (1971) Measurement of water movement in reference to benthic algal growth. Bot Mar 14:32-35

Fine M, Oren U, Loya Y (2002) Bleaching effect on regeneration and resource translocation in the coral Oculina patagonica. Mar Ecol Prog Ser 234:119-125

Fisher EM, Fauth JE, Hallock P, Woodley CM (2007) Lesion regeneration rates in reef-building corals Montastraea spp. as indicators of colony condition. Mar Ecol Prog Ser 339:61-71

Ginsburg RN, Gischler E, Kiene WE (2001) Partial mortality of massive reef-building corals: an index of patch reef condition, Florida Reef Tract. Bull Mar Sci 69:1149-1173

Goreau T, McClanahan T, Hayes R, Strong A (2000) Conservation of coral reefs after the 1998 global bleaching event. Conserv Biol 14:5-15

Guillaume M (1988) La croissance du squelette de Porites lutea, scléractiniaire hermatypique, sur le récif frangeant de la Saline, île de la Réunion, océan Indien. PhD thesis, University of Aix-Marseille II, Marseille
Henry LA, Hart M (2005) Regeneration from injury and resource allocation in sponges and corals - a review. Int Rev Hydrobiol 90:125-158

> Hoegh-Guldberg O, Mumby PJ, Hooten AJ, Steneck RS and others (2007) Coral reefs under rapid climate change and ocean acidification. Science 318:1737-1742

> Houlbrèque F, Ferrier-Pagès C (2009) Heterotrophy in tropical scleractinian corals. Biol Rev Camb Philos Soc 84:1-17

> Hughes TP, Jackson JBC (1985) Population dynamics and life histories of foliaceous corals. Ecol Monogr 55:141-166

> Jones RJ (2008) Coral bleaching, bleaching-induced mortality, and the adaptive significance of the bleaching response. Mar Biol 154:65-80

- Kohler KE, Gill SM (2006) Coral point count with Excel extensions (CPCe): a visual basic program for the determination of coral and substrate coverage using random point count methodology. Comput Geosci 32:1259-1269

Kramarsky-Winter E, Loya Y (2000) Tissue regeneration in the coral Fungia granulosa: the effect of extrinsic and intrinsic factors. Mar Biol 137:867-873

> Lester RT, Bak RPM (1985) Effect of environment on regeneration rate of tissue lesions in the reef coral Montastrea annularis (Scleractinia). Mar Ecol Prog Ser 24:183-185

Levy JM (2009) Global oceans. In: Peterson TC, Baringer MO, Knight J, Kennedy JJ and others (eds) State of the climate in 2008. Bull Am Meteorol Soc 90: 1-196

> Lough JM, Barnes DJ (2000) Environmental controls on growth of the massive coral Porites. J Exp Mar Biol Ecol 245:225-243

McClanahan TR, Maina J, Moothien-Pillay R, Baker AC (2005) Effects of geography, taxa, water flow, and temperature variation on coral bleaching intensity in Mauritius. Mar Ecol Prog Ser 298:131-142

> Meesters EH, Bak RPM (1993) Effects of coral bleaching on tissue regeneration potential and colony survival. Mar Ecol Prog Ser 96:189-198

Meesters EH, Bos A, Gast GJ (1992) Effects of sedimentation and lesion position on coral tissue regeneration. Proc 7 th Int Coral Reef Symp 2:681-688

> Meesters EH, Noordeloos M, Bak RPM (1994) Damage and regeneration: links to growth in the reef-building coral Montastrea annularis. Mar Ecol Prog Ser 112:119-128

> Meesters EH, Pauchli W, Bak RPM (1997) Predicting regeneration of physical damage on a reef-building coral by regeneration capacity and lesion shape. Mar Ecol Prog Ser 146:91-99

Mioche D, Cuet P (1999) Métabolisme du carbone, des carbonates et des sels nutritifs en saison chaude, sur un récif frangeant soumis à une pression anthropique (île de la Réunion, Océan Indien). CR Acad Sci Ser IIa Sci Terre Planètes 329:53-59

> Nagelkerken I, Bak RPM (1998) Differential regeneration of artificial lesions among sympatric morphs of the Caribbean corals Porites astreoides and Stephanocoenia michelinii. Mar Ecol Prog Ser 163:279-283

Naim O (1993) Seasonal responses of a fringing reef community to eutrophication (Réunion Island, Western Indian Ocean). Mar Ecol Prog Ser 99:137-151

Naim O (2006) The structure of coral reef benthic communities at Saint-Gilles la Saline in 1987 (Réunion, Mascarene Archipelago, SW Indian Ocean). J Nat 18:13-31

Naim O, Cuet P, Letourneur Y (1997) Experimental shift in benthic community structure. Proc 8th Int Coral Reef Symp 2:1873-1878

Oren U, Rinkevich B, Loya Y (1997a) Oriented intra-colonial transport of ${ }^{14} \mathrm{C}$ labeled materials during coral regeneration. Mar Ecol Prog Ser 161:117-122 
Oren U, Benayahu Y, Loya Y (1997b) Effect of lesion size and shape on regeneration of the Red Sea coral Favia favus. Mar Ecol Prog Ser 146:101-107

Oren U, Benayahu Y, Lubinevsky H, Loya Y (2001) Colony integration during regeneration in the stony coral Favia favus. Ecology 82:802-813

Rasher DB, Hay ME (2010) Chemically rich seaweeds poison corals when not controlled by herbivores. Proc Natl Acad Sci USA 107:9683-9688

Rinkevich B (1996) Do reproduction and regeneration in damaged corals compete for energy allocation? Mar Ecol Prog Ser 143:297-302

Scopélitis J, Andréfouët S, Phinn S, Chabanet P, Naim O, Tourrand C, Done T (2009) Changes of coral communities over 35 years: integrating in situ and remote-sensing data on Saint-Leu Reef (la Réunion, Indian Ocean). Estuar Coast Shelf Sci 84:342-352

Sebens KP, Grace SP, Helmuth B, Maney EJ Jr, Miles JS (1998) Water flow and prey capture by three scleractinian corals, Madracis mirabilis, Montastrea cavernosa and Porites porites, in a field enclosure. Mar Biol 131:347-360

Sokal RR, Rohlf FJ (1995) Biometry. WH Freeman, San Francisco, CA

Editorial responsibility: Tim McClanahan, Mombasa, Kenya
Stevens J (2002) Applied multivariate statistics for the social sciences, 4th edn. Lawrence Erlbaum Assoc., Mahwah, NJ

Titlyanov EA, Titlyanova TV (2008) Coral-algal competition on damaged reef. Russ J Mar Biol 34:199-219

> Titlyanov EA, Titlyanova TV (2009) The dynamics of the restoration of mechanical damage to colonies of the scleractinian coral Porites lutea under conditions of competition with algal settlers for substratum. Russ J Mar Biol 35: 230-235

Titlyanov EA, Titlyanova TV, Yakovleva IM, Nakano Y, Bhagooli R (2005) Regeneration of artificial injuries on scleractinian corals and coral/algal competition for newly formed substrate. J Exp Mar Biol Ecol 323:27-42

van Woesik R (1998) Lesion healing on massive Porites spp. corals. Mar Ecol Prog Ser 164:213-220

Ward S (1995) Two patterns of energy allocation for growth, reproduction and lipid storage in the scleractinian coral Pocillopora damicornis. Coral Reefs 14:87-90

- Warner M, Chilcoat G, McFarland F, Fitt W (2002) Seasonal fluctuations in the photosynthetic capacity of photosystem II in symbiotic dinoflagellates in the Caribbean reefbuilding coral Montastraea. Mar Biol 141:31-38

Submitted: May 17, 2010; Accepted: January 26, 2011 Proofs received from author(s): April 6, 2011 